\title{
THE HINDRANCES TO GOOD CITIZENSHIP
}

\author{
BY \\ JAMES BRYCE
}

\author{
NEW HAVEN: YALE UNIVERSITY PRESS \\ IONDON: HUMPHREY MILFORD \\ OXFORD UNIVERSITY PRESS \\ MDCCCCIX
}

